H. Markiewicz, Czytanie Irzykowskie-

go, Universitas, Kraków 2011

\title{
Przyjemność lektury
}

ABSTRACT. Bulanowski Marek Oktawian, Przyjemność lektury [Pleasure of reading]. „Przestrzenie Teorii" 22. Poznań 2014, Adam Mickiewicz University Press, pp. 263-267. ISBN 978-83-2322827-1. ISSN 1644-6763.

Henryk Markiewicz's book Czytanie Irzykowskiego [Readings of Irzykowski] is a collection of studies dedicated to the work of a leading Polish modernist critic who was also an influential theorist, historian of literature and author of the experimental novel titled Pałuba. Although this collection does not constitute a monograph on Karol Irzykowski's work, the variety of methodological approaches that are presented in the articles reveals Markiewicz's characteristic interests and shows that contemporary literary studies focus on reading and history rather than theory (P. de Man). These studies were influenced by the ideas of Russian formalists (B. Eichenbaum), semiotics and Marxism; however, Markiewicz does not faithfully adhere to any methodological school. Above all, his studies show that he is interested in literariness, literary works of art, the history of ideas and correct interpretation.

Czytanie Irzykowskiego to rezultat trwającej kilka lat przygody literackiej Henryka Markiewicza. Jej wynik w postaci niedawno wydanej przez krakowskie wydawnictwo Universitas książki z pewnością zaciekawi czytelnika interesującego się dziejami modernizmu w Polsce. Składa się ona z dziesięciu studiów, w większości publikowanych wcześniej na łamach m.in. „Ruchu Literackiego”, „Tekstów”, „Pamiętnika Literackiego”, „Twórczości” i kilku ksiąg zawierających prace ofiarowane wybitnym badaczom. Lektura - choć raczej należałoby powiedzieć: lektury Markiewicza - nie obejmują całości dorobku twórczego Karola Irzykowskiego, gdyż zainteresowania autora Dziesiątej muzy były bardzo rozległe. Pasjonował się on nie tylko literaturą, wypowiadał się także na temat teatru i filmu ${ }^{1}$ (co było na początku XX wieku działalnością pionierską na grun-

${ }^{1}$ Por. K. Irzykowski, Dziesiata muza oraz pomniejsze pisma filmowe, tekst opracowała i indeksy sporządziła Z. Górzyna, Kraków 1982; tenże, Pisma teatralne, [w:] tegoż, Pisma, t. 4, teksty zebrała i opracowała J. Bahr, Kraków 1997. Od problematyki teatrologicznej jednak Markiewicz całkowicie nie stroni. Por. jego omówienia refleksji działalności krytycznej Irzykowskiego poświęconej dramaturgii Stefana Żeromskiego (H. Markiewicz, 
cie polskim), a był również autorem wierszy i awangardowej powieści Pałuba ${ }^{2}$. Zatem o przygodach lektury Markiewicza można powiedzieć, że są rezultatem przyjemności literackich, jakie wzbudziła w nim bogata spuścizna Irzykowskiego. Henryk Markiewicz zauważa:

Karol Irzykowski wypowiadał się w różnych formach pisarstwa krytycznoliterackiego: są wśród nich recenzje, portrety i sylwetki, artykuły sprawozdawcze, informacyjne i przeglądowe. Ale przede wszystkim pasjonowały go problemy ogólne literatury jako swoistej wiedzy o człowieku i jako techniki artystycznej³

Zatem celem lektury Irzykowskiego przyjętym przez Markiewicza nie jest ujęcie monograficzne. Taka książka już zresztą się ukazała, a jest nią praca Barbary Winklowej Karol Irzykowski, życie i twórczość ${ }^{4}$. Tym niemniej, badając różne aspekty pisarstwa Irzykowskiego, takie jak jego strategie pisarskie, stosunek do kultury niemieckiej, działalność krytyczną i literacką, poglądy estetyczne, styl pisarski itp., Markiewicz daje podstawę do dalszych badań, jak i podsumowuje dotychczasowe. Nie jest to moje odkrycie, bo Henryk Markiewicz jest znany ze swojej niezwykłej rzetelności wobec omawianych przez niego autorów. Podjęcie badań nad bardzo zróżnicowanym dorobkiem autora Pałuby sprawiło, że teksty jemu poświęcone także są różnorodne metodologicznie, co powoduje, że czytelnik je czyta z uwagą i rosnącym apetytem poznawczym.

Jaki zatem ujawnia się obraz pisarstwa Irzykowskiego w świetle lektury Markiewicza? Wydaje się, że tekst poświęcony poetyce mówi wiele o technice pisarskiej i sposobie budowy tekstów krytycznych autora $P a$ luby. Jest on zresztą jednym $\mathrm{z}$ najciekawszych wśród zamieszczonych studiów Markiewicza, który, jak się zdaje, uważa w ślad za strukturalistami i semiotykami, że badania nad konstrukcją tekstów są nadal ciekawe i stymulujące poznawczo, gdyż ujawniają ewolucję strategii krytycznych w dziedzinie literaturoznawstwa oraz wykazują historyczność jego osiągnięć. I tak Markiewicz zauważa, że pisarstwo Irzykowskiego charakteryzowało się skłonnością do polemiki, dramatycznością, dialogicznością, kolokwializmem (s. 5), metaforycznością stylu (s. 6), dygresyjnością (s. 8), ironicznością (s. 15), a jego teksty wyróżniały się na tle ówczesnego pisarstwa krytycznego "grawitującego ku patetyczności” (s. 5).

W ksztalt linii meandrycznej, [w:] tegoż, Czytanie Irzykowskiego, passim, Kraków 2011) czy Stanisława Wyspiańskiego i Antoniego Słonimskiego (tamże, Paradoksy i palinodie, s. 53-62; tamże, Szachy i majcher, s. 125).

2 Tenże, Nowele, opr. tekstu J. Grodzicka, Kraków 1979; tenże, Wiersze, Kraków 1977; tenże, Pałuba. Sny Marii Dunin, opr. A. Budrecka et. al., Wrocław, Kraków 1981.

${ }^{3}$ H. Markiewicz, Czytanie Irzykowskiego, Kraków 2011, s. 5.

${ }^{4}$ B. Winklowa, Karol Irzykowski, życie i twórczość, Kraków 1987. 
Markiewicz jednak nie jest ortodoksyjnym strukturalistą, skupiającym się na badaniach ergocentrycznych. Wydaje się mniemać, że zainteresowania budową tekstów powinny prowadzić do pytań badawczych koncentrujących się na znaczeniu zdań i tekstów i historii. Interesują go więc także zagadnienia $\mathrm{z}$ zakresu historii idei, ujęte intertekstualnie, a konkretnie związki Irzykowskiego z kulturą niemiecką (patrz rozdział Wobec kultury niemieckiej). Markiewicz zauważa, że nasza wiedza o nich jest jeszcze mała. Pisze więc: „Związki pisarstwa Irzykowskiego z kulturą niemiecką, zbadane dotąd tylko we fragmentach, oczekują na gruntowne ujęcie systematyczne. Zanim się ono pojawi, spróbujmy zestawić i uporządkować ich najważniejsze, łatwo widoczne przejawy" (s. 26).

Wbrew zapowiedzi skromnie postawionego sobie zadania Markiewicz szuka śladów fascynacji kulturą niemiecką u Irzykowskiego już w jego dziecięcych lekturach. Nie są to tylko przypomnienia erudyty, lecz analiza wnosząca nowe spojrzenie na zainteresowania modernistycznego krytyka literaturą i filozofią niemiecką. Irzykowski czytał namiętnie dzieła Ottona Ludwiga, Schillera, Goethego, Kleista, Grabbego, Uhlanda, Lessinga, Wernera, Hebbla, Macha, Freuda, Adlera, Marksa i Engelsa i in. Markiewicz w swoim studium pokazuje, że wczesne oczarowania kulturą niemiecką Irzykowskiego nie były czymś przejściowym, były one kontynuowane i pogłębiane przez całe życie, co jest widoczne w jego twórczości, w której widać głęboką znajomość osiągnięć współczesnej mu literatury i filozofii niemieckiej, przejawiającej się nie tylko w apologetycznych artykułach i recenzjach, lecz także w próbach translatorskich.

Problem pisania literackiego i krytycznego to nie tylko zagadnienie konstrukcji tekstów, lecz także styl. Irzykowski nie był jedynym krytykiem, który interesował się tym zagadnieniem, a w szczególności - ustosunkowując się do tradycji młodopolskich i pojawienia się twórczości awangardowej - przyczynił się do dyskusji nad zagadnieniem niezrozumialstwa. Pod tym pojęciem kryło się zjawisko zawiłości i niejasności stylu wielu pisarzy i krytyków końca XIX i początku XX wieku. Markiewicz podjął się zbadania tego problemu u Irzykowskiego, choć budził on ciekawość zarówno Włodzimierza Boleckiego, jak i Ryszarda Nycza ${ }^{5}$. Studium Rozgatunkowanie niezrozumialstwa jest poświęcone głównie Irzykowskiemu, jednak Markiewicz omawia problem w szerszym kontekście przywołując ówczesne opinie, jako że „niezrozumialstwo” było postrzegane różnie, bo też miało różne oblicza. Wynikało ono, twierdzi Markiewicz, z braków warsztatowych, manieryzmu i płycizn intelektualnych, ale też wraz z pojawieniem się awangardy $-\mathrm{z}$ dążenia do poszukiwania nowych

${ }^{5}$ Por. W. Bolecki, Poetycki model prozy $w$ dwudziestoleciu międzywojennym, Wrocław 1982, s. 253-257; R. Nycz, Język modernizmu, Wrocław 1997, s. 165-183. 
form i eksperymentu, jak w wypadku poezji Przybosia. Irzykowski często występował przeciwko „niezrozumialstwu”, jednak, jak dostrzegł Markiewicz, popierając swoje spostrzeżenia wieloma przykładami, autor $B e$ niaminka nie ustrzegł się tego grzechu pisarskiego.

Markiewicz poświęcił kilka studiów działalności krytycznej Karola Irzykowskiego. Dzięki temu czytelnik ma możliwość zapoznania się także z jego poglądami estetycznymi. Z badań Markiewicza wynika, że Irzykowski był krytykiem kontrowersyjnym. Jego zamiłowanie do polemik i często nietrafne diagnozy wywoływały sprzeciw. W rozdziale Paradoksy $i$ palinodie badacz przypomina między innymi opublikowaną anonimowo recenzję omawianego krytyka w sprawie Wesela, które, cytuję za Markiewiczem, nie miało nerwu dramatycznego i posiadało wiele innych, trudnych do wybaczenia grzechów. Irzykowski musiał swoje „idiotyczne” i „kompromitujące” tezy odwoływać, bo jak twierdził później, nie wyrażały one jego autentycznej opinii. Opisanie stosunku Irzykowskiego nie tylko do Wyspiańskiego, lecz także do innych pisarzy, w tym tak popularnych jak Tadeusz Boy-Żeleński, to problem niezwykle pasjonujący, dzisiaj znany głównie historykom, choć wiele mówi o historii poglądów estetycznych modernizmu, którego przecież nie można traktować jako monolit.

Takim dziełem, które z pewnością jest łakomym kąskiem dla badaczy historii estetyki modernistycznej, jest z pewnością Beniaminek. Markiewicza interesuje w nim przede wszystkim budowa tekstu. W ślad za Borysem Eichenbaumem oraz samym Karolem Irzykowskim stawia pytanie: jak został zrobiony Beniaminek?6. Badanie Markiewicza jest jednak osadzone w kontekście historycznym, co sprawia, że czytelnik obcuje nie tylko z „nagą" strukturą tekstu, lecz odbiera go w żywym kontekście literackim. W konkluzji Markiewicz interesuje się pojmowaniem literatury u Irzykowskiego, a można by dodać, że ciekawe byłoby zbadanie tego pojęcia w szerszym ujęciu historycznym rozumienia literatury $\mathrm{w}$ dobie modernizmu. Autor Głównych problemów wiedzy o literaturze pisze, że Irzykowski postulował walkę o „literaturę bez reszty nowatorską, na najwyższym stopniu literackiego skomplikowania, wolną od kompromisów praktycznych, nieprzejednanie wierną wartościom duchowym”7.

Drugim adwersarzem Irzykowskiego, obok Boya-Żeleńskiego, był Antoni Słonimski. Markiewicz, co ciekawe, nie śledzi losów sporów krytycznych i literackich pomiędzy tymi dwoma wielkimi osobowościami literac-

${ }^{6}$ K. Irzykowski podobnie tytułuje rozdział swej książki: Jak ja to robię; por. także: B. Eichenbaum, Jak jest zrobiony Płaszcz Gogola?, [w:] Rosyjska szkoła stylistyki, red. M.R. Mayenowa, Warszawa 1970.

7 Tamże, s. 108. 
kimi, by przedstawić tylko fragment dyskusji literackich dwudziestolecia, lecz zwraca uwagę na... styl. Wydaje się, że to nowoczesne podejście do badań nad krytyką ujawnia literacki status krytyki. Markiewicz pisze w konkluzji: „Jeśli warto się tym sporom bliżej przyjrzeć, to dlatego, że egzemplifikują one w sposób ekstremalny te właśnie rejestry stylistyczne międzywojennych dyskusji literackich"8.

Uwaga o literackim aspekcie krytyki jest dobrym pretekstem, by zwieńczyć książkę mocnym akcentem, bo czyż można sobie wyobrazić twórczość Karola Irzykowskiego bez Pałuby? Markiewicz temu wyjątkowemu dziełu poświęca swoje ostatnie studium. Wnikliwa i drobiazgowa analiza powieści oraz historia komentarzy do niej według Markiewicza potwierdza postawioną tezę jej autora o „bezimienności” Pałuby, co należy rozumieć jako jej niedefiniowalność.

Jak zatem rozumieć pisarskie strategie Markiewicza? Wydaje się, że na tle jego pisarstwa ostatnich lat Czytanie Irzykowskiego to pozycja, która ma cechy charakterystyczne dla sposobu myślenia autora. Widać w niej większy pierwiastek analityczny i osobisty. Zamiłowanie do precyzji i jasności stylu połączone z chłodnym dystansem wobec badanego tekstu jest w niej widoczne, jednak Markiewicz bardziej jest zainteresowany aspektami ludycznymi, subiektywnymi, czyli tym, co literackie. Odchodząc od języka bardzo abstrakcyjnego, dochodzi do samego tekstu i wydaje się dawać czytelnikowi do zrozumienia, że tym, co go interesuje, jest po prostu literatura w różnych jej kontekstach i sposobach istnienia oraz odbioru.

8 Tamże, s. 126. 